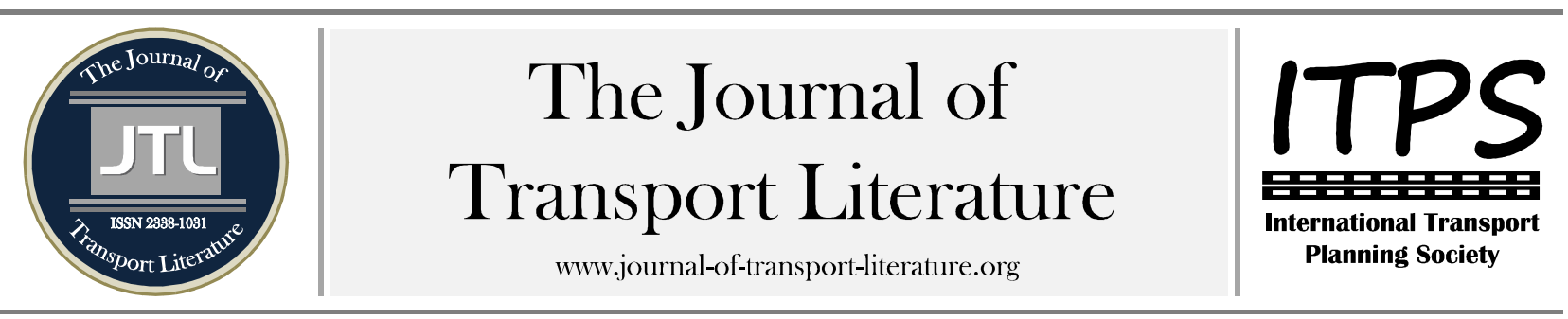

\title{
A framework of performance indicators used in the governance of logistics platforms: the multiple-case study
}

Rafael Mozart da Silva ${ }^{1,+}$; Eliana Terezinha Pereira Senna ${ }^{1}$; Orlando Fontes Lima Júnior ${ }^{1}$; Luiz Afonso dos Santos Senna ${ }^{2}$

1 University of Campinas, Campinas, Brazil

2 Federal University of Rio Grande do Sul, Porto Alegre, Brazil

\section{Article Info}

Keywords:

Logistics Platforms

Governance Indicators

Logistics

Governance Logistics

Submitted 16 Jan 2014;

received in revised form 28 Aug 2014; accepted 8 Oct 2014 .

Licensed under

Creative Commons

CC-BY 3.0 BR.

\section{Abstract}

The logistics platform (PL) can be understood as a place where different actors in the supply chain could be integrated in the same physical location and with this, obtain a greater synergy among the various logistical processes. That enabling an improvement in the level of logistical service provided to the client and representing a competitive advantage for the permanence of these organization's in the market where they operate. The objective of this research was to elaborate a framework of performance indicators that could be used in the governance of logistics platforms based on bibliographical research on performance indicators in the business environment and logistics indicators. To achieve the proposed objective, a multiple cases study with leaders of logistic platforms located in Zaragoza, Valencia, and Barcelona in Spain was carried out. As a result a set of twenty seven performance indicators were identified. That presented a high degree of importance and can contribute to the governance of logistics platforms. The results from this study can contribute to observations and applications regarding the use of indicators in the governance of logistics platforms.

+ Corresponding author. Cidade Universitária Zeferino Vaz. Rua Saturnino de Brito, 224. Campinas - SP. CEP 13083-889.

E-mail address: rafmozart@terra.com.br.

\section{Introduction}

Global competition has currently been changing the way that products are manufactured and also transported worldwide, which has imposed new conditions to the organizations so that they can act in this scenario. The creation and use of logistics centers have come as an alternative given the current level of dynamism and competitiveness. Logistics centers allow greater synergy between the participating organizations, generating benefits such as the shared use of a logistics infrastructure, the possibility of increased productivity, a reduced customer order cycle, the generation of innovation in services and added value to the end product (Notteboom; Rodrigue, 2005; Mccalla; Salck; Comtois, 2001; Silva et al. 2013a).

In logistics platforms logistic activities are performed (storage, cargo shipment, cross-docking and the like) and it is recommended that procedures be standardized and measured. The use of a logistics platform may be a source of competitive advantage by integrating activities within a specific supply chain scenario, which is seen as a key factor for the success of many companies. One of the main characteristics and prerequisites of the logistics platform concept concerns its objectives, which must be set by its participants. A logistics platform includes concepts of integrated logistics regarding physical structure, processes and operational activities, as well as information systems needed for the development of operations and reporting (Aldin; Stahre, 2003; Dias et al., 2009; Campolongo; Morandi; Mariotti, 2010; Cambra-Fierro; RuizBenitez, 2009; Silva et al. 2014; Mazzarino, 2012; Gajsek; Lipicnik; Simenc, 2012; Abrahamsson; Aldin; Stahre, 2003; Crainic; Ricciardi; Storchi, 2004).

Logistics activities and logistics services performed in a logistics platform are diverse, ranging from stocking, cargo handling, consolidation and deconsolidation, and even product industrialization. The management of logistics platforms can be private, public or a mix of the two forms. Generally the management of these enterprises is centralized and is responsible for operations planning, budgeting and also administration and support for local operations. Because of the different activities and actors involved in a logistics platform, the governance of such venture has a key role in the proper operation, performance and achievement of the proposed objectives (Tsamboulas; Kapros, 2003; Dias et al., 2009; Rimienė; Grundey, 2007; Meidutè , 2007; Pettit; Beresford, 2009; Sheffi, 2013).

From a literature review on performance indicators in the business environment and also logistical indicators, the objective of this research was to develop a framework of performance indicators that can be used in the governance of logistics platforms. In order to achieve the proposed objective, a multiple case study was carried out with managers of logistics platforms in Spain. The degree of importance that a set of performance indicators has in the governance of these enterprises and complex logistical arrangements were assessed. 
Section 1 presents the research methodology used for this study. The general considerations regarding Survey respondents are presented in Section 2. The multiple case study and the analysis and discussion of results are presented in Section 3. Finally, Section 4 shows the conclusions and contributions of this work, which can be used as hypotheses for further research.

\section{Research methodology}

Regarding the nature of this research, it was classified as "applied". Applied research aims to generate knowledge for practical applications, which can be directed at solving specific problems and may involve local truths and interests. Regarding approach, this research is both qualitative and quantitative. Quantitative research is characterized by the use of quantification, both in the collection and in processing data by using statistical techniques, in order to avoid possible distortions of analysis and interpretation and allowing greater safety margin (Diehl, 2004; Richardson, 1989; Rosental; Frémontier-Murphy, 2001). According to Flick (2004), qualitative research is oriented towards the analysis of concrete cases in their temporal and local particularity, based on people's expressions and attitudes in their local contexts.

According to Gil (2010), this research was classified as exploratory regarding its objective, since it seeks greater familiarity with the problem and make it more explicit. Collins and Hussey (2005) argue that exploratory research aims to find patterns, ideas or hypotheses because a more open method is used, in which the focus is on gathering broad data and views on the phenomenon studied. The technical procedure used in this study was the multiple-case study. According to Yin (2004), a case study may be single or multiple, because the multiple-case study is a form of research that investigates a contemporary phenomenon within its context and a reality, especially when the boundaries between phenomenon and context are not clearly defined. Yin (2004) also defines the case study as a research that aims to clarify a decision or set of decisions, i.e., why they were decided, how they were implemented and what the results were.

For the structuring and development of this research publications on governance and performance indicators developed by Silva et al. (2013a, 2013b) and Silva Senna (2013), Silva, Senna and Lima Jr. (2013), Bertom (2003), Galvão, Correa and Alves (2011), Savitz and Weber (2007) and Ethos (2012) were initially used as a theoretical basis. The next section presents a brief reference about governance and also the performance indicators identified in the published works, which served as the basis for multiple case studies.

\section{Survey respondents}

In this section the development of a multiple case study is presented, which was carried out in three logistics platforms in Spain. This research was carried out by means of in-depth interviews with four managers of logistics platforms, which are in the top management in the companies visited. Individual in-depth interviews allow greater analysis and understanding of the purpose of research, because researchers make use of inductive strategies, raising and checking information that can be translated into concepts and practices that build a more consistent approach to research (Flick, 2004; Ribeiro; Milan, 2004). The sample of survey respondents is presented in Table 1 :

\begin{tabular}{ccccc}
\multicolumn{5}{c}{ Table 1 - Sample of survey respondents. Source: authors. } \\
\hline Respondents & Job position & Company & Time with company & Equity \\
\hline R1 & Commercial Director & LP - Zaragoza & 12 years & Public-Private \\
R2 & General Director & LP - Valencia & years & Public-Private \\
R3 & General Manager & 4 years & Public-Private \\
R4 & General Director & *Saba Parques Logísticos & 5 years & Private \\
\hline * Saba Parques Logísticos - Owner of 9 logistics platforms in Europe. LP- Logistics Platform / LPs - Logistics Platform
\end{tabular}

A set script of questions was used by the researchers, which was the basis for the overall direction and conduct of interviews. It is important to stress that additional questions during the interviews were asked, since the instrument above mentioned served as a script, thus allowing a greater degree of flexibility with the interviewees. With the script in hand, the interviews were conducted in Spanish, the respondents' native language. The possibility to conduct the interview in the respondents' native language allowed them to get more comfortable to expose their ideas and opinions.

\section{Multiple case study}

In the first phase of interviews, the questions asked focused on a qualitative approach, in which aspects of governance structure and actions in logistics platforms were contemplated. Below is a summary of the data and information collected from the respondents, including some excerpts from the interviews.

\subsection{Governance in logistics platforms}

The understanding and analysis of governance models used in logistics platforms are key not only to determine how economic activities are distributed in logistics platforms, but also to highlight the relationship between the parties, the trade-off related to actual and potential earnings and also to contribute to the development of these projects in the current scenario, whether local or global. The mutual cooperation between the different actors of a logistics platform is a point that should be constantly worked on, because it is difficult for those involved to plan their activities in order to meet not only their own interests, but the goals of the other members of these logistical arrangements (Silva et al. 2013b; Higgins; Ferguson, 2011). The use of a measurement system and performance indicators in the governance of logistics platforms becomes essential to the achievement of the proposed objectives and also to minimize the asymmetry of power between the parties that make up these logistical developments (Silva et al., 2013a; 2013b)

In the phase of the interviews, the proposal for the framework of performance indicators used in governance of logistics platforms was submitted to the respondents, where it was found the degree of importance of each indicator assigned by respondents. A survey instrument was prepared based on the conceptual framework of usable indicators on governance of LPs (table 1) that contained 41 performance indicators (resulting from the literature review), distributed in 8 dimensions. The indicators were described in the survey form, and the respondents attributed the degree of importance for each indicator, according to its relevance when used in the governance of the logistical platforms, being ranked: 1-not important, 
2-Low importance, 3-somewhat important, 4-Indifferent, 5-Important 6-Very Important and 7- Extremely important. While developing the scales, the response patterns among multiple items are weighed.

The likert measurement scale is widely used in research because a numerical rating is given to each answer in order to reflect the opinion of the respondent regarding the subject investigated (Saraph, Benson and Schroeder, 1989; Cooper and Schindler, 2003). Two control questions were used in the data collection instrument: i) taking into consideration the performance indicator structure proposed, in your opinion, what is the degree of importance of each indicator in governance of logistics platform?; and ii) Is there any other performance indicators on governance of logistics platform which are not part of the proposed structure? If Yes, what are those indicators?

The following aspects were used in the analysis of the responses; Respondents' Answer Frequency and the Indicators Score, which took into account the number of times that each indicator was chosen in each of the seven degrees of importance. Moreover, the answers obtained from respondents were also multiplied by the degree of importance, being that the total score could range from $0 \leq 28$ by indicator.

After calculating the score of the degree of importance for each indicator, an analysis of the indicators per dimensions was performed and presented $\geq 21$ points, i.e., degree of importance $\geq 75$, which is equivalent to the very important and extremely important levels of importance. In addition to checking the level of importance of the performance indicators used in the governance of the logistical platforms by the respondents, they were asked whether there were other indicators of performance to consider. Six other performance indicators were suggested by the respondents, which are; i) occupancy rate of the LP (\%), ii) Total $\mathrm{m}^{2}$ sold, iii) Total leased spaces, iv) employment Rate in the region where the LP is installed, v) Total expenditure with third parties, and vi) projects developed in partnership with the companies installed. The additional indicators were incorporated to the others and all of them were consolidated and are presented in Table 2 below:

\begin{tabular}{|c|c|c|c|c|}
\hline \multirow[b]{2}{*}{ Dimension } & \multirow[b]{2}{*}{ Performance Indicator } & \multicolumn{3}{|c|}{ Type of PL Governance } \\
\hline & & Public & Private & $\begin{array}{l}\text { Public and } \\
\text { Private }\end{array}$ \\
\hline \multirow{9}{*}{ Financial } & Net Operating Revenue & - & - & $\mathrm{x}$ \\
\hline & Return on equity (ROE) & & - & $\mathrm{x}$ \\
\hline & Return on Assets (ROA) & - & - & $\mathrm{x}$ \\
\hline & Return on Investment (ROI) & - & - & $\mathrm{x}$ \\
\hline & Operating costs & - & - & $\mathrm{x}$ \\
\hline & $\%$ Overall liquidity & - & - & $\mathrm{x}$ \\
\hline & Fixed costs & - & - & $\mathrm{x}$ \\
\hline & Net Cash Flow & - & - & $\mathrm{x}$ \\
\hline & Total expenditure with third parties & $\mathrm{x}$ & - & - \\
\hline \multirow{3}{*}{ Supplier } & $\begin{array}{l}\text { Effectiveness of the LP management to resolve technical } \\
\text { problems }\end{array}$ & - & - & $\mathrm{x}$ \\
\hline & Projects developed in partneship with installed companies & - & - & $\mathrm{x}$ \\
\hline & Level of information and shared processes & - & - & $\mathrm{x}$ \\
\hline \multirow{7}{*}{ Governance } & $\begin{array}{c}\text { Service and complaint ombudsman availability for the } \\
\text { stakeholders }\end{array}$ & - & - & $\mathrm{x}$ \\
\hline & Commitment to the organization mission and values & - & - & $\mathrm{x}$ \\
\hline & Issuance and Disclosure of Financial reports & - & - & $\mathrm{x}$ \\
\hline & Occupancy rate of the LP $(\%)$ & - & - & $\mathrm{x}$ \\
\hline & Total $\mathrm{m}^{2}$ sold & $\mathrm{x}$ & - & $\mathrm{x}$ \\
\hline & Total leased spaces & - & $\mathrm{x}$ & $\mathrm{x}$ \\
\hline & Employment Rate in the region where the LP is installed & - & - & $\mathrm{x}$ \\
\hline $\begin{array}{c}\text { HR and } \\
\text { Knowledge }\end{array}$ & Level of employee satisfaction & - & - & $\mathrm{x}$ \\
\hline \multirow{5}{*}{$\begin{array}{l}\text { Customer } \\
\text { Service* }\end{array}$} & Rate of customer satisfaction with the service or product & - & - & $\mathrm{x}$ \\
\hline & Prompt assistance in cases of malfunction of the product & - & - & $\mathrm{x}$ \\
\hline & Flexibility to meet customers' special needs & - & - & $\mathrm{x}$ \\
\hline & Number of customer complaints & - & - & $\mathrm{x}$ \\
\hline & Service time for customer order & - & - & $\mathrm{x}$ \\
\hline \multirow[t]{2}{*}{ Sustainability } & $\begin{array}{c}\text { Compliance with environmental law in local, State, and } \\
\text { federal levels }\end{array}$ & - & - & $\mathrm{x}$ \\
\hline & Waste treatment & - & - & $\mathrm{x}$ \\
\hline
\end{tabular}

Initially 41 performance indicators were presented to the respondents. Of those, 21 indicators or $51.22 \%$ were considered of high level of importance. In an open question, the respondents were asked to report whether there were other indicators to consider besides the ones that had already been demonstrated in the indicators framework. A total of six other indicators were added from the respondents, totaling a structure of 27 performance indicators used in the governance of logistics platforms.

Based on the answers from R1, R2, R3 and R4, It was noticed in which logistic platform mode (public, private, or public and private) the indicators could be used in governance, and, as a result, it was found that $85.19 \%$ (23 indicators) apply to public or private platforms, $3.70 \%$ (1 indicator) apply to private platforms and $11.11 \%$ (3 indicators) can be used in public platforms. This assessment is based on the respondents' opinions.

According to R1 and R2, the use of performance indicators on governance of logistics platform is "a necessity and enables a greater control from the administrator's point of view ". At Zaragoza logistics platform, the Government holds $51 \%$ of the controlling interest of the Plaza capital, which requires the same efficient management mechanisms and controls. For R3, the use of performance indicators provides greater visibility regarding the platform situation, and enable "managers to focus on action to an specific problem". According to R4, the indicators relate to "the activity management control, the business strategy, the strategy, the Capex, and the "exploration". All the respondents corroborate the idea that the performance indicators are very important in governance of logistics platforms. 
Finally, it was asked to the respondents what would be the future challenges for the governance of logistics platforms, and the responses are summarized below:

- Zaragoza Logistics platform (Plaza): to R1, the main challenges are related to; i) development and greater integration of internal processes, mainly by allowing a greater synergy among the logistics platform participating organizations, ii) the marketing of available land, because, due to the current economic scenario in Spain, still under effects of the crisis of 2008, the region is operating below the projected objectives and iii) the internationalization of LPs, attracting other companies from other companies and continents pas to settle in the Plaza. The challenges cited by R2 were; i) perform a greater control and financial management, avoiding episodes of "deviations" such as the one which was recently discovered, ii) transparency in transactions with the customers, iii) limitation to the managers' powers, and iv) studies for infrastructure adjustments, allowing greater mobility in cargo handling;

- Valencia Logistics platform: according to R3, the platform future plans are focused on the sales (leasing) of available areas, because it took years of planning and execution of the project. The enterprise's governance-related issues will be held during the installation of new companies;

- Saba logistics parks: according to R4, among the future challenges are i) the constant search for new customers, since the currently contractual cycle ranges from 2 to 3 years, ii) logistic platforms must be part of a strategic plan by the Government, because the issues involving infrastructure (railways, highways, airports and waterways) are essential to the LPs operations, i.e., There should be an open dialogue between the Government and the companies to make the new projects feasible.

It is evident that the future challenges for the logistics platforms reported by respondents involve not only aspects related to management, but also to relationship issues (client, Government, administration and market). The agglomeration of various actors in the same environment highlights the need for a proper alignment of objectives on the part of those involved, and, on the face of it, it is paramount that a framework need to be built that that the governance actions must be monitored so that the logistics platforms may respond appropriately to the stakeholders' goals.

\section{Conclusion}

Regarding the objective initially proposed for this research, which consisted of drawing up a performance indicator framework that can be used in governance of logistics platforms, it is understood that it has been reached, since the research included both a thorough literature review on indicators and governance and conducted a study of multiple cases in Spain with four executives from large and influent logistics platforms within the European Community.

Logistics platforms can be considered complex logistical ventures, because in addition to the activities developed in the environment, many LPs are composed of a large number of participating companies. Considering the diversity of elements that composes a logistics platform, governance-related aspects of this type of enterprise are extremely important to meet the expectations of the various participants and the success of a logistics platform, demanding that an appropriate system to monitor the PL performance from the government agents.

The interviews conducted in loco by the respondents allowed researchers to have a greater visibility on how logistics platforms are managed and also ratified the necessity of the use of performance indicators in the governance of these endeavors. The results obtained through the findings obtained with the individual interviews and with the in-depth interviews allowed the researchers to draw up a framework of performance indicators, which took account of financial and non-financial indicators. According to Kaplan and Norton (1992), who comment that many organizations adopt a broad set of indicators of financial and non-financial performance in order to capture the essence of their actual performance. To the authors, the performance indicators should overcame the use of the indicators for controlling purposes only, that is, it must go beyond the grip of actions based on previously established plans, to actually collaborate with the organization's strategy.

From the qualitative and quantitative analysis of the interviews, a set of 27 performance indicators that can be used in governance of logistics platforms was obtained. The indicators are contained in six dimensions, which can be understood as a category, a perspective, a field and/or a reference environment where the attributes to measure organizational performance are set and systematized. The financial dimension is composed of 9 indicators, corresponding $33.33 \%$ of the performance indicators identified in the research. The governance dimension includes 7 indicators, i.e., $25.93 \%$ of total, followed by the customer service dimension with 5 indicators (18.52\%), supplier with 3 indicators $(11.11 \%)$ sustainability, with 2 indicators $(7.41 \%)$ and human resources and Knowledge with $3.70 \%$ represented by 1 indicator.

Performance measurement used by the governance of logistics platforms is a broad and current theme, and it has been discussed over the years by various authors, but what is noticed from the literature review is that there is a certain uniqueness about a clear definition of which indicators can contribute and be used in the governance of the LPs. The research may represent a contribution to the academic and professional field, because the performance indicator framework proposed in this research can be used in the governance of logistics platforms for government agents, in order to enable the same increased visibility on the platform performance on various aspects, since the proposed framework covers different dimensions. The robustness of the indicators structure proposed was based on the bibliographic survey and also on implementation through in-depth interviews with the leaders of large logistics platforms located in Europe, which totalize over $20,348,438 \mathrm{~m}^{2}$ and involve more than 15,000 employees.

However, it is believed that there is still much to be developed in this regard. As a suggestion for future research, a multiple case study in logistics platforms located in Asia, North America and other continents should be carried out in order to verify which indicators are used in the governance of logistics platforms and also to apply the performance indicator framework proposed in this research to devise a benchmarking among logistics platforms, once the instrument from this study provides standardized data collection.

A final contribution of this study is its results, which can be used as hypotheses for the development of new observations and applications about the use of indicators in the governance of logistics platforms. 


\section{References}

Abrahamsson, M., Aldin, N., \& Stahre, F. (2003). Logistics platforms for improved strategic flexibility. International Journal of Logistics Research and Applications, 6(3), 85-106.

Aldin, N., \& Stahre, F. (2003). Electronic commerce, marketing channels and logistics platforms - a wholesaler perspective. European Journal of Operational Research, 144(2), 270-279.

Berton, L. H. (2003) Indicadores de desempenho e as práticas de boa governança corporativa. Tese de Doutorado em Engenharia de Produção, Universidade Federal de Santa Catarina, Florianópolis, SC.

Cambra-Fierro, J., \& Ruiz-Benitez, R. (2009). Advantages of intermodal logistics platforms: insights from a Spanish platform. Supply Chain Management: An International Journal, 14(6), 418- 421.

Campolongo, M., Morandi, C., \& Mariotti, I. (2010). La piattaforma logistica di Leixões, Portogallo, e il suo território. Journal of Land Use. Mobility and Environment, 3(2), 65-72.

Collins, J., \& Hussey, R. (2005). Pesquisa em administração: um guia prático para alunos de graduação e pós-graduação. Porto Alegre: Bookman, $2^{\circ}$ Edition.

Cooper, D. R., \& Schindler, P. S. (2003). Métodos de Pesquisa em Administração. São Paulo: Bookman, 7oㅡ Edition.

Crainic, T. G., Ricciardi, N., \& Storchi, G. (2004). Advanced freight transportation systems for congested urban areas. Transportation Research Part C: Emerging Technologies, 12(2), 119-137.

Dias, J. C. Q., Calado, J. M. F., Osório, A. L., \& Morgado, L. F. (2009). RFID together with multi-agent systems to control global value chains. Annual Reviews in Control, 33(2), 185-195.

Diehl, A. (2004). Pesquisa em ciências sociais aplicadas: métodos e técnicas. São Paulo: Prentice Hall.

Flick, U. (2004). Uma introdução à pesquisa qualitativa. 2nd ed. Porto Alegre: Bookman.

Gajsek, B., Lipicnik, M., \& Simenc, M. (2012) The logistics platform disambiguation. Research in Logistics \& Production, 2(1), 69-80.

Galvão, H. M., Corrêa, H. L., \& Alves, J. L. (2011). Modelo de avaliação de desempenho global para instituição de ensino superior. Revista de Administração da UFSM, 4, 425-441.

Gil, A. C. (2010). Como Elaborar Projetos de Pesquisa. 5th edition São Paulo: Atlas.

Higgins, C. D., \& Ferguson, M. R. (2011). An Exploration of the Freight Village Concept and its Applicability to Ontario. McMaster Institute of Transportation and Logistics. McMaster University. Hamilton, Ontario.

Instituto Ethos de Empresas e Responsabilidade Social. (2012) Indicadores Ethos para Negócios Sustentáveis e Responsáveis, 2012. Available in <http://www.ethos.org.br.> Accessed on: October 14, 2013.

Kaplan, R. S., \& Norton, D. P. (1992). The balanced scorecard: measures that drive performance. Harvard Business Review, 70(1), 71-79.

Mazzarino, M. (2012). Strategic scenarios of global logistics: what lies ahead for Europe? European Transport Research Review, 4(1), 1-18.

Mccalla, R. J., Slack, B., \& Comtois, C. (2001). Intermodal Freight Terminals: Locality and Industrial Linkages. The Canadian Geographer, $45(3), 404-413$.

Meidutè, I. (2007). Economical evaluation of logistics centres establishment. Transport, 22(2), 111-1117.

Notteboom, T. E., \& Rodrigue, J. P. (2005). Port Regionalization: Towards a New Phase in Port Development. Maritime Policy and Management, 32(3), 297-313.

Pettit, S. J. \& Beresford, A. K. C. (2009) Port development: from gateways to logistics hubs. Maritime Policy and Management. v. 36, n. 3, pp. 253-267

Ribeiro, J. L. D., \& Milan, G. S. (2004). Planejando e conduzindo entrevistas individuais. In: RIBEIRO, José Luis Duarte; MILAN, Gabriel Sperandio (Eds.). Entrevistas individuais: teoria e aplicações (pp. 9-22). Porto Alegre: FEEng/UFRGS.

Richardson, R. J. (1989). Pesquisa social: métodos e técnicas. São Paulo: Atlas.

Rimienė, K. \& Grundey, D. (2007). Logistics Centre Concept through Evolution and Definition. Engineering Economics, 4(1), 87-95.

Rosental, C. \& Frémontier-Murphy, C. (2001). Introdução aos métodos quantitativos em ciências humanas e sociais. P. Alegre: Inst. Piaget.

Saraph, J. V., Benson, P. G., \& Schroeder, R. G. (1989) An instrument for measuring the critical factors of quality management. Decision Sciences, 20(4), 810-829.

Savitz, A. W., \& Weber, K. (2007). A empresa sustentável: o verdadeiro sucesso é lucro com responsabilidade social e ambiental. Rio de Janeiro: Elsevier.

SheffI, Y. (2013). Logistics Intensive Clusters: Global Competitiveness and Regional Growth, in James Bookbinder (Ed.),Handbook of Global Logistics (pp. 463-500). New York: Springer Science+Business Media.

Silva, R. M., Senna, E. T. P., Senna, L. A. dos S., \& Lima Júnior, O. F. (2013a). Logistics Platform: A framework based on systematic review of the literature. Paper presented at 22nd International Conference on Production Research (ICPR 22), Foz do Iguaçu.

Silva, R. M., Senna, E. T. P., Senna, L. A. D. S., \& Lima Júnior, O. F. (2013b). Governança em plataformas logísticas: uma análise dos elementos e atributos a serem considerados neste tipo de empreendimento logístico. Journal of Transport Literature, 7(3), 240-269.

Silva, R. M., \& Senna, E. T. P. (2013). Um framework de indicadores de desempenho aplicados a governança de plataformas logísticas. Paper presented at XXVII ANPET - Congresso de Pesquisa e Ensino em Transportes, Belém.

Silva, R. M., Senna, E. T. P., \& Lima Júnior, O. F. (2013). Governança em Plataformas Logísticas: A aplicabilidade dos atributos e indicadores de desempenho logístico. Paper presented at Ibero American Academy of Management - 8th International Conference, São Paulo.

Silva, R. M. , Senna, E. T. P., Senna, L. A. D. S. \& Lima Júnior, O. F. (2014). Plataformas Logísticas: uma abordagem sobre as tipologias e características através de uma revisão sistemática. Journal of Transport Literature, 8(1), 210-234.

Tsamboulas, D. A., \& Kapros, S. (2003). Freight Village Evaluation Under Uncertainty With Public And Private Financing. Transport Policy, $10(2), 141-156$.

Yin, Robert K. (2004). Estudo de caso: planejamento e métodos. 3rd ed. Porto Alegre: Bookman. 